
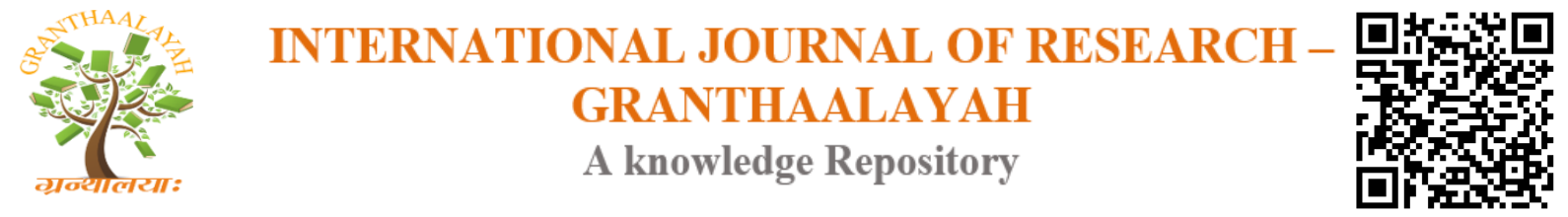

RASM - 17

\title{
WATER QUALITY ANALYSIS: A CASE STUDY IN BYRAMANGALA LAKE WATER AND SURROUNDING GROUND WATER
}

\author{
H. Babitha Rani ${ }^{1}$, Dimple Bahri ${ }^{1}$, Prabin Neupane ${ }^{2}$, Kunal Kothari ${ }^{2}$, Vishal Gadgihalli ${ }^{2}$, \\ Raghavendra Prasad Havanje Dinakar ${ }^{3,4}$, Amritha M George ${ }^{2}$, P Pavani Reddy ${ }^{2}$, Vasavi \\ Reddy Pasula $^{2}$, Kamalakshi Deginal ${ }^{2}$ \\ ${ }^{1}$ Assistant Professor, Department of Civil Engineering, SET, Jain University, India \\ ${ }^{2}$ UG student, Department of Civil Engineering, SET, Jain University, India \\ ${ }^{3}$ Research Assistant, Department of Civil Engineering, SET, Jain University, India \\ ${ }^{4}$ Centre for Emerging Technology, Jain University, India
}

DOI: https://doi.org/10.29121/granthaalayah.v5.i4RASM.2017.3373

\begin{abstract}
A study was carried out to find out the water quality of Byramangala lake of Ramanagara district. The water quality of Byramangala lake water and ground water from bore wells situated in the area within 600 meters surrounding the lake was analyzed. The quality analysis of various parameters such as BODs, COD, DO, E-Coli, and pH, Total Dissolved Solids, Total Suspended Solids and Total Hardness were tested. In addition, the presence of metals such as Cadmium $(\mathrm{Cd})$, Chromium $(\mathrm{Cr})$, Lead $(\mathrm{Pb})$, and Iron $(\mathrm{Fe})$ in the lake water and ground water samples were tested. Results for the various tests conducted showed similar trends for both lake water and ground water. It was observed that certain parameters such as BOD5, and COD were beyond permissible limits as per the BIS standards for drinking water. A few remedial measures have been proposed that may help in mitigating the pollution in the selected project area Byramangala Lake.
\end{abstract}

Keywords: Byramangala Lake; Water Quality; Ground Water; Quality Analysis; Remedial Measures.

Cite This Article: H. Babitha Rani, Dimple Bahri, Prabin Neupane, Kunal Kothari, Vishal Gadgihalli, Raghavendra Prasad Havanje Dinakar, Amritha M George, P Pavani Reddy, Vasavi Reddy Pasula, and Kamalakshi Deginal. (2017). "WATER QUALITY ANALYSIS: A CASE STUDY IN BYRAMANGALA LAKE WATER AND SURROUNDING GROUND WATER." International Journal of Research - Granthaalayah, 5(4) RASM, 71-77. https://doi.org/10.29121/granthaalayah.v5.i4RASM.2017.3373. 
[Rani et. al., Vol.5 (Iss.4: RASM), April, 2017]

ICV (Index Copernicus Value) 2015: 71.21

Recent Advances in Sustainable Materials
ISSN- 2350-0530(O), ISSN- 2394-3629(P)

IF: 4.321 (CosmosImpactFactor), 2.532 (I2OR)

InfoBase Index IBI Factor 3.86

\section{Introduction}

One of the major crises faced in the recent times is the strain on the potable water resources. Bangalore city originally met its water demand from the lakes and tanks which were constructed across the city in the 16th century. The lakes that were once a source of water for irrigation, drinking, fishing etc are now used as dumping sites for industrial effluents, domestic sewage, domestic solid waste etc [1]

In this research Byramangala Lake of Ramanagara District has been chosen as study area. The lake joins river Arkavathi downstream, which ultimately joins the river Cauvery. The pollution of the lake began in the 1960's. The main sources of pollution are the industrial effluents, the municipal effluents and the untreated sewage discharge from the Bangalore urban area, which eventually enters the Vrishabhavathi reservoir. The right bank of the lake houses a large industrial zone known as the Bidadi Industrial Area. Most of these industries discharge their effluents into the Byramangala Lake without subjecting the effluents to secondary or advanced treatment. [2] Industrial effluents were collected from three different stations during the year 2011 and 2012 for three different seasons and analyzed. COD concentration recorded was comparatively high during pre-monsoon season due to high temperatures and low dilution. The alkalinity of water was much higher than the Indian standard [3]. Conceptual Design of a wastewater treatment plant for the DeraBassi industrial estate, Punjab (2013) shows that overall goal of the project was to prevent the contamination of the aquifer [4].

Studies on heavy metal contamination in Vrishabhavathi river water and groundwater of the surrounding river (2013) aims to assess the physicochemical parameter, extent of heavy metal content in Vrishabhavathi River and its surrounding ground water Toxic heavy metal analysis was done using atomic absorption spectrophotometer. Heavy metals $\mathrm{Pb}, \mathrm{Cr}, \mathrm{Ni}, \mathrm{Mn}$ and $\mathrm{Fe}$ concentrations were found to be above permissible limit [2].

Evaluation of water quality in and around Byramangala Reservoir (2015) of three villages was taken into consideration Byramangala, Bannigere and MG doddi. The samples were collected thrice in the months of February, April and June and in all. Twenty five samples were tested for sixteen chemical parameters. Heavy metals like Nickel, copper and chromium were found to be at higher rate during the rainy days indicating the dangerous effect of leaching. Other parameters such as pH, Calcium hardness, Chlorides, Nitrate, Sodium and Potassium were oscillating around permissible limits. Fluoride concentration was found to be high and around $2.3 \mathrm{mg} / \mathrm{l}$. Water quality index values were $16 \%-28 \%$, poor with respect to drinking water quality [5].

\section{Materials and Methods}

\section{Study Area}

The study area geographically lies between $12^{\circ} 45^{\prime} 48^{\prime \prime} \mathrm{N}$ and $77^{\circ} 25^{\prime} 36^{\prime \prime E}$. Byramangala Lake situated in Ramanagara district was originally constructed by the British in the year 1942 in view of providing the local residents with clean water for irrigation, domestic use, fisheries etc. the quality of the lake has drastically changed over the years. 
The following is the Google location map showing the sample collection points.

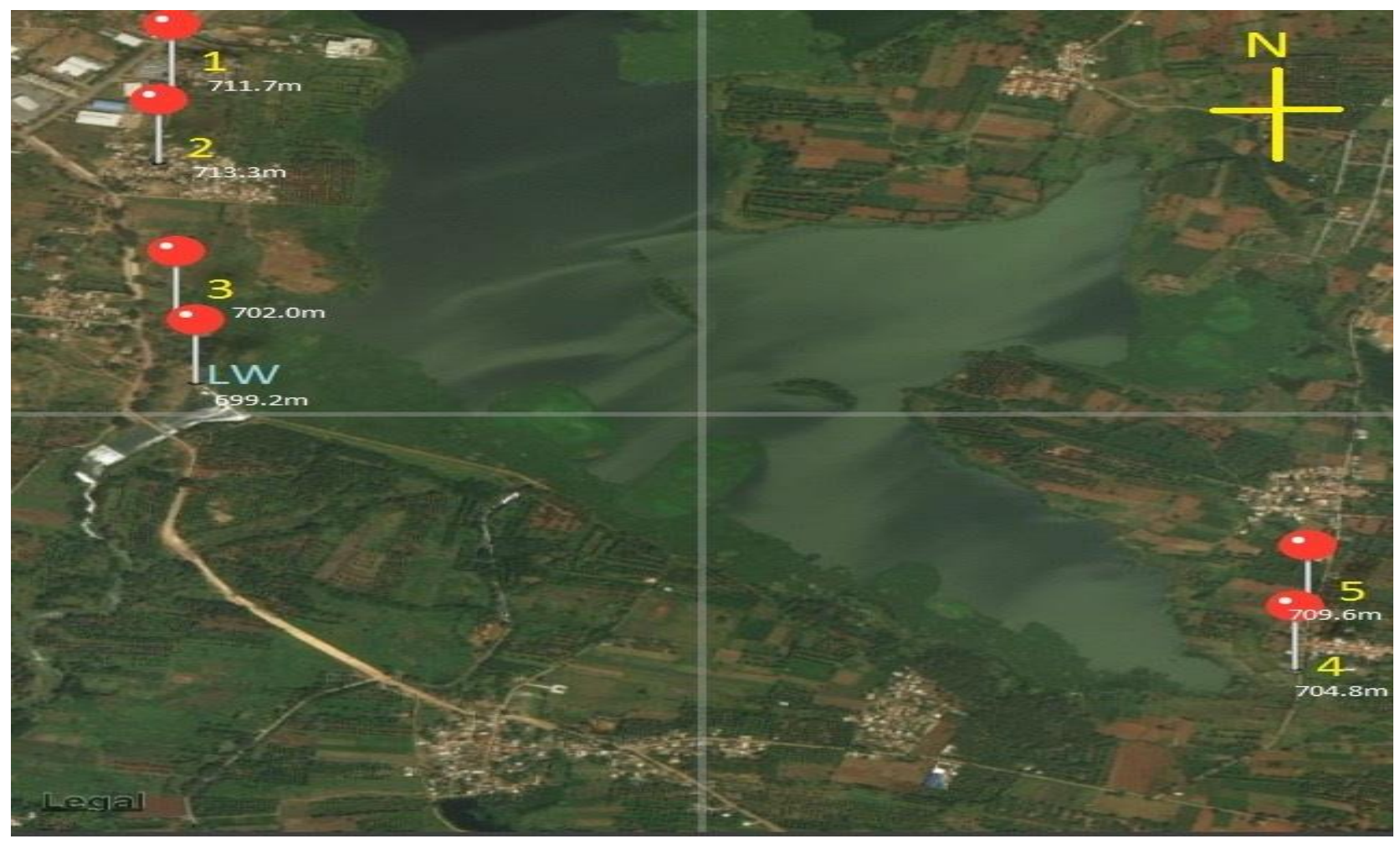

\section{Materials}

Water quality analysis of water from the lake and the water from the bore wells in the area within 600 meters radius surrounding the lake was carried out. The parameters such as BOD5, COD, DO, E-Coli, pH, Total Dissolved Solids, Total Suspended Solids and Total Hardness were tested. The presence of four metals, Iron, Chromium, Cadmium and Lead in the water samples were also tested.

\section{Methods}

Groundwater samples from five locations and lake water sample from a particular location were tested for physicochemical parameters. The values were then compared with the standard permissible limits. Ground water sample and lake water sample were analyzed for the presence of metal contaminants.

\section{Collection Method}

A visual inspection of the site was done and some of the aspects were noted. Potential pollution sources are Bidadi industrial area on the right bank, agricultural fields on the left bank, domestic, animals. Condition of water was cloudy, color, smell, foam. The samples collected were tested for the physicochemical parameters within 8 hours from collection. The samples collected for metal content testing were tested within 24 hours from collection. 
Table 1: Details of collection points and time of sample collection

\begin{tabular}{|c|c|c|c|c|c|c|}
\hline $\begin{array}{c}\text { Sample } \\
\text { no. }\end{array}$ & $\begin{array}{c}\text { Latitude } \\
\text { of } \\
\text { location }\end{array}$ & $\begin{array}{c}\text { Longitude } \\
\text { of } \\
\text { location }\end{array}$ & $\begin{array}{l}\text { Elevation(above } \\
\text { mean sea level } \\
\text { in meter) }\end{array}$ & $\begin{array}{c}\text { Distance } \\
\text { from } \\
\text { the lake } \\
\text { banks }\end{array}$ & $\begin{array}{c}\text { Time/date of } \\
\text { sample collection }\end{array}$ & Remarks \\
\hline 1. & 12.7699 & 77.4166 & 711.7 & $400-410$ & $\begin{array}{c}9: 40 \mathrm{am} / 15 / 3 / 17 \\
\& \\
12: 00 \mathrm{pm} / 12 / 4 / 17\end{array}$ & $\begin{array}{l}\text { Right } \\
\text { bank, } \\
\text { Near RI } \\
\text { industry }\end{array}$ \\
\hline 2. & 12.7675 & 77.4164 & 713.3 & $380-400$ & $\begin{array}{c}9: 30 \mathrm{am} / 15 / 3 / 17 \\
\& \\
12: 05 \mathrm{pm} / 12 / 4 / 17\end{array}$ & $\begin{array}{l}\text { Right } \\
\text { bank near } \\
\text { road }\end{array}$ \\
\hline 3. & 12.7698 & 77.4167 & 702.2 & $530-540$ & $\begin{array}{c}9: 50 \mathrm{am} / 13 / 3 / 17 \\
\& \\
12: 20 \mathrm{pm} / 12 / 4 / 17\end{array}$ & $\begin{array}{l}\text { Brick } \\
\text { factory }\end{array}$ \\
\hline 4. & 12.7514 & 77.4357 & 704.8 & $380-400$ & $\begin{array}{c}11: 00 \mathrm{am} / 15 / 3 / 17 \\
\& \\
12: 30 \mathrm{pm} / 1 / 4 / 17\end{array}$ & $\begin{array}{l}\text { Left bank } \\
\text { near } \\
\text { sugarcane } \\
\text { fields }\end{array}$ \\
\hline 5. & 12.7533 & 77.4359 & 709.6 & 270 & $\begin{array}{c}11: 15 \mathrm{am} / 15 / 3 / 17 \\
\& \\
12: 40 \mathrm{pm} / 12 / 4 / 17 \\
10: 30 \mathrm{am} / 15 / 3 / 17\end{array}$ & $\begin{array}{c}\text { Left bank } \\
\text { near lake } \\
\text { border }\end{array}$ \\
\hline 6 & 12.7605 & 77.4170 & 699.2 & - & $\begin{array}{c}\& \\
1: 00 \mathrm{pm} / 12 / 4 / 17\end{array}$ & \\
\hline
\end{tabular}

\section{Methodology}

The physic- chemical parameters to be tested are chosen based on the literature review regarding the same. The eight parameters chosen to be tested are COD, BOD5, DO, E-Coli, pH, Total Hardness, Total Suspended Solids (TSS) and Total Dissolved Solids (TDS). The sample collection location is chosen on the basis of proximity to the Byramangala Lake. Samples were collected by standard procedure from five ground water collection location and one particular location in the lake. The samples were collected in the months of March and April. The collected samples were tested for the eight chosen physicochemical parameters. One ground water sample (having values beyond the permissible limit for the parameters tested) and one lake water sample were analyzed for four heavy metal contaminants. The metal contaminants were chosen based on the literature review regarding the same. The metal contaminants were tested for Lead $(\mathrm{Pb})$, Iron (Fe), Cadmium (Cd) and Chromium (Cr).

\section{Results and Discussions}

The discharges of untreated sewage, municipal and industrial effluents are a few of the major factors contributing to the pollution of the lake [1]. The pollution of the lake water has led to the decrease in the groundwater quality in the area around the lake[2]. In the present study quality analysis of the lake water and groundwater from bore wells in the area around the lake, is carried 
out, to see if a correlation exists between the two. Remedial measures are proposed according to the results of the analysis, which can help in mitigating the pollution in the lake and also provide portable groundwater to the local residents.

The results of the physicochemical parameters as well as metal containments tested are given below:

\section{Results for Samples Collected in the Month of March}

The following table shows the results of physicochemical parameters tested in the month of March.

Table 2: Results of tests conducted for Physicochemical parameters (March 2017)

\begin{tabular}{ccccccccc}
\hline Parameter & Unit & $\begin{array}{c}\text { Sample } \\
\mathbf{1}\end{array}$ & $\begin{array}{c}\text { Sample } \\
\text { 2 }\end{array}$ & $\begin{array}{c}\text { Sample } \\
\text { Sample }\end{array}$ & $\begin{array}{c}\text { Sample } \\
\mathbf{4}\end{array}$ & $\begin{array}{c}\text { Lake } \\
\text { water } \\
\text { sample }\end{array}$ & $\begin{array}{c}\text { BIS limit } \\
\text { for } \\
\text { drinking } \\
\text { water }\end{array}$ \\
pH & Moles/l. & 7 & 7 & 7.2 & 7.3 & 7.5 & 7.4 & 6.5 to 8.5 \\
Hardness & $\mathrm{mg} / \mathrm{l}$ & 600 & 510 & 450 & 500 & 588 & 230 & 600 \\
COD & $\mathrm{mg} / 1$ & 43 & 47 & 460 & 340 & 280 & 350 & 250 \\
BOD5 & $\mathrm{mg} / 1$ & 51 & 14.5 & 30.1 & 65.6 & 85.4 & 105 & 30 \\
DO & $\mathrm{mg} / 1$ & 4 & 6.5 & 5.2 & 4.2 & 3.9 & 3.4 & 4.5 \\
E-Coli & - & 4 & 10 & 35 & 46 & 58 & - & Nil/100ml \\
Total & $\mathrm{mg} / 1$ & 494 & 585 & 1230 & 964 & 1200 & 1000 & - \\
solids & & & & & & & & \\
TDS & $\mathrm{mg} / 1$ & 440 & 450 & 760 & 870 & 660 & 488 & 2000 \\
TSS & $\mathrm{mg} / 1$ & 560 & 700 & 1000 & 800 & 1400 & 1850 & - \\
\hline
\end{tabular}

\section{Results for Samples Collected in the Month of April}

The following table shows the results of the physicochemical parameters tested for in the month of April.

Table 3: Results of tests conducted for Physicochemical parameters (April 2017)

\begin{tabular}{|c|c|c|c|c|c|c|c|c|}
\hline Parameter & Unit & $\begin{array}{c}\text { Sample } \\
1\end{array}$ & $\begin{array}{c}\text { Sample } \\
2\end{array}$ & $\begin{array}{c}\text { Sample } \\
3\end{array}$ & $\begin{array}{c}\text { Sample } \\
4\end{array}$ & $\begin{array}{c}\text { Sample } \\
5\end{array}$ & $\begin{array}{c}\text { Lake } \\
\text { water } \\
\text { sample }\end{array}$ & $\begin{array}{c}\text { BIS } \\
\text { Limit for } \\
\text { drinking } \\
\text { water }\end{array}$ \\
\hline $\mathrm{pH}$ & Moles/1 & 7 & 7 & 7.3 & 7.5 & 7.4 & 7.6 & 6.5 to 8.5 \\
\hline Hardness & $\mathrm{mg} / \mathrm{l}$ & 660 & 580 & 468 & 568 & 610 & 280 & 600 \\
\hline COD & $\mathrm{mg} / \mathrm{l}$ & 40 & 40 & 480 & 360 & 250 & 320 & 250 \\
\hline BOD5 & $\mathrm{mg} / \mathrm{l}$ & 58 & 17.4 & 32.9 & 72.5 & 98.6 & 116 & 30 \\
\hline DO & $\mathrm{mg} / \mathrm{l}$ & 3.7 & 5 & 4 & 3.8 & 2 & 2.8 & 4.5 \\
\hline E-Coli & - & 5 & 12 & 42 & 55 & 60 & - & $\mathrm{Nil} / 100 \mathrm{ml}$ \\
\hline $\begin{array}{l}\text { Total } \\
\text { solids }\end{array}$ & $\mathrm{mg} / \mathrm{l}$ & 500 & 600 & 1300 & 1000 & 1400 & 1200 & - \\
\hline TDS & $\mathrm{mg} / \mathrm{l}$ & 450 & 500 & 800 & 900 & 700 & 500 & 2000 \\
\hline TSS & $\mathrm{mg} / \mathrm{l}$ & 660 & 800 & 1100 & 900 & 1500 & 2000 & - \\
\hline
\end{tabular}




\section{Results of the Metal Contaminants}

Certified company for water quality analysis the result of the metal contaminants tested in the particular ground water sample is as follows:

Table 4: Results of tests conducted for metal contaminants in groundwater sample

\begin{tabular}{|c|c|c|c|c|}
\hline $\begin{array}{l}\text { Sl. } \\
\text { No. }\end{array}$ & Parameters & Test method & Results & $\begin{array}{l}\text { Is } 10500: 2012 \\
\text { Drinking water } \\
\text { Specification } \\
\text { requirement } \\
\text { (Acceptable limit) }\end{array}$ \\
\hline 1. & Iron as $\mathrm{Fe}$ & IS:3025(part 53) & $<0.1$ & Maximum $0.3 \mathrm{mg} / \mathrm{l}$ \\
\hline 2. & Cadmium as $\mathrm{Cd}$ & IS:3025(part 41) & $<0.003$ & Maximum $0.003 \mathrm{mg} / 1$ \\
\hline 3. & Chromium as $\mathrm{Cr}$ & IS:30259part 52) & $<0.01$ & Maximum $0.05 \mathrm{mg} / 1$ \\
\hline 4. & Lead as $\mathrm{Pb}$ & IS:3025(Part 47) & $<0.01$ & Maximum $0.01 \mathrm{mg} / \mathrm{l}$ \\
\hline
\end{tabular}

The result of the metal contaminants tested in the lake water sample is as follows:

Table 5: Results of tests conducted for metal contaminants in lake water sample

\begin{tabular}{|c|c|c|c|c|}
\hline Sl. No. & Parameters & Test method & Results & $\begin{array}{c}\text { Is } 10500: 2012 \text { Drinking } \\
\text { water Specification } \\
\text { requirement } \\
\text { (Acceptable limit) }\end{array}$ \\
\hline 1. & Iron as $\mathrm{Fe}$ & IS:3025(part 53) & $<0.1$ & Maximum $0.3 \mathrm{mg} / \mathrm{l}$ \\
\hline 2. & Cadmium as $\mathrm{Cd}$ & IS:3025(part 41) & $<0.003$ & Maximum $0.003 \mathrm{mg} / \mathrm{l}$ \\
\hline 3. & Chromium as $\mathrm{Cr}$ & IS:30259part 52) & $<0.01$ & Maximum $0.05 \mathrm{mg} / 1$ \\
\hline 4. & Lead as $\mathrm{Pb}$ & IS:3025(Part 47) & $<0.01$ & Maximum $0.01 \mathrm{mg} / \mathrm{l}$ \\
\hline
\end{tabular}

\section{Conclusions}

It is observed that the Bio Chemical Oxygen Demand (BOD) and the Chemical Oxygen Demand (COD) are beyond permissible limits prescribed by BIS (Bureau of Indian Standards) for sample 3,4 and 5. This clearly indicates that the water is polluted with organic matter. The results of tests conducted for Iron, Cadmium, Chromium and Lead shows that these metals are present in the water samples, both in the groundwater and the lake water, but are within permissible limits as per IS 10500: 2012. An increase in the concentration can pose a threat to the wellbeing of the population residing in and around the area. Hence the concentration of these metals in the water must be kept under check.

\section{Remedial measures}

\section{Construction of a Wastewater Treatment Plant}

Most of the industries from the Bidadi industrial area discharge their effluents into the Byramangala Lake without subjecting the effluents to secondary or advanced treatment [2]. The construction of a waste water treatment plant for treating the effluents from the major large scale industries before discharging into the Byramangala Lake can help in mitigating the pollution in the lake. 
A conceptual design of a waste water treatment plant to treat the effluents from a few large scale industries of the Bidadi industrial area before being discharged into the Byramangala Lake is proposed.

The Components of the Treatment Plant in the Conceptual Design are mentioned below:

The treatment process consists of

1) Screening

2) Grit removal

3) Primary clarification

4) Aerobic process (Aeration tanks) / Attached growth system (Trickling filters)

5) Secondary clarification

6) Sludge thickening

7) Sludge digesting

Portable Activated Carbon Filters: The portable filters can be used at the site of the bore well. The water drawn from the bore well can be passed through the filter system and then used for the various domestic needs. This system of filtration keeps a check on the COD and BOD levels in the bore well water. Activated Carbon Filter are used to reduce chlorine, organics, color, tannin, objectionable tastes and odors, and dissolved organic chemicals from municipal and industrial water supplies

Green Bridge: Green Bridge technology is Eco technological horizontal filtration - having different physical and biological filters working in combination removes suspended and dissolved impurities of water.

\section{Mechanical Aerator}

Oxygen-transfer rate of mechanical aerators: Surface aerators are rated in terms of their oxygen-transfer rate or $\mathrm{kg}$ of oxygen per $\mathrm{kW}$-hour $(\mathrm{kW}-\mathrm{hr})$ at standard conditions. Surface aerators normally have an oxygen transfer efficiency of 1.2 to $2.4 \mathrm{~kg} 02 / \mathrm{kW}-\mathrm{hr}$ while turbine aerators have oxygen transfer efficiency of 2 to $3 \mathrm{~kg}$. 02/kW-hr.

\section{References}

[1] Madhukar R and Srikantaswamy S (2013). Impact of industrial effluents on water quality of Vrishabhavathi river and Byramangala Lake in Bidadi area. International journal of Geology, Earth and Environment Sciences. 3(2)p.p132-141.

[2] Jayadev and E.T Puttiah (2013). Studies on heavy metal contamination in Vrishabhavathi river water and ground water of the surrounding. International journal of scientific and engineering research 4.

[3] Jan, Nasrut, Nandini, N., Jumbe, about S. and S. Anupama B. (2008). Impact of municipal and industrial pollution on Byramangala Lake, Bangalore Rural district, India. The 12th World Lake Conference, 1717-1728.

[4] Farid Ansari and Yashwant K. Pandey (2013). Conceptual design of Waste water treatment plant for the Dera Bassi Industrial Estate, Punjab (India). 13(4).

[5] L Uday Simha and Mahesh Babu (2015). Evaluation of water quality in and around Byramangala reservoir. List B scientific journals 8(2) p.p 215-221.

E-mail address: babithahemah@ yahoo.com 